\title{
Cured dry smoked shoulder meat quality from culled adult goats fed a high lipid diet
}

\author{
Felipe Brener Bezerra de OLIVEIRA ${ }^{1}$, César Carneiro Linhares FERNANDES², Assis Rubens MONTENEGRO², \\ Iolly Tabata Marques OLIVEIRA², Caroline Pessoa SILVA², Francisco Wellington Rodrigues LIMA², \\ Hilton Alexandre Vidal CARNEIRO², Frederico José BESERRA ${ }^{3}$, Aníbal Coutinho do RÊGO ${ }^{1 \star ~(D), ~}$ \\ Davide RONDINA ${ }^{2}$
}

\begin{abstract}
The effect of high dietary lipid on the meat quality parameters of shoulder meat adult goats in raw meat and during curing and smoking was evaluated by classical and multivariate approaches. The animals were divided into two groups of different finishing strategies: without whole full-fat linseed (WFFLG, $n=9$ ) and whole full-fat linseed (FFLG, $\mathrm{n}=9$ ), with diets containing an ether extract content of $2.7 \%$ and $6.9 \%$, respectively. The physicochemical attributes did not vary according to the experimental diets in raw meat. The colorimetric parameters and $\mathrm{pH}$ varied during curing and smoking. Through multivariate analysis the first two principal components (PC), it was possible to identified variables were highly importance the total variation $\left(\mathrm{L}^{*}, \mathrm{a}^{*}, \mathrm{~b}^{*}\right.$, $\mathrm{C}^{\star}, \mathrm{h}^{\star}$, and fat content) in raw meat and smoking. The fat content and color $\mathrm{b}^{\star}$ presented the highest scores for importance of the variable in the projection. Lipid supplementation of adult goats did not influence the quality parameters physicochemical of the raw shoulder meat. However, after curing and smoking there was a significant effect of diet on Hue angle $\left(h^{\star}\right)$.
\end{abstract}

Keywords: small ruminant; linseed; meat; processed products.

Practical Application: Shoulder meat curing and smoking as an alternative to adult "cull" goat carcasses.

\section{Introduction}

Goat meat is known worldwide as an important component of the human diet because of its nutritional (low fat and cholesterol) and sensory (flavor, juiciness, and tenderness) characteristics, which distinguish it from other species (Madruga \& Bressan, 2011). Therefore, goat meat is a healthier alternative compared to other types of red meat.

However, some factors influence the quality characteristics of the meat, one of which is the age at slaughter. The young animals (goat kids) have a meat which is more appreciated and higher valued (animals slaughtered at 8-12 weeks or 6-8 kg live weight). Old goat meat (from mature animals) is associated with a stronger flavor and less juiciness and tenderness. The meat of heavier animals (between 2 and 6 years of age and weighing between 20 and $30 \mathrm{~kg}$ ), especially the older ones culled at the end of their productive life ( $>6$ years old), is much less appreciated (Madruga \& Bressan, 2011). This type of mature goat meat is considered more suitable for processing as a dry, cured, or smoked product (Teixeira et al., 2019).

Another important factor is the production system and the nutritional protocol, which can influence both the growth characteristics and the quality parameters of the meat, such as color, consistency, and the composition of fatty acids in muscle fat and adipose tissue (Webb \& O’Neill, 2008). Concentrate supplementation during the dry season or for finishing discarded goats is a common management strategy. Among the main dietary strategies, lipids can be used because of their potential energy supply; their inclusion in feed increases the total digestible nutrients (TDN) of the diet (Fiorentini et al., 2013).

Despite the importance of the goat farming sector in the context of Brazilian livestock, in recent years, there have been few technological advances in goat meat processing that can improve the quality of goat meat and offer consumers new product alternatives. In some countries, goat meat is consumed after curing and maturation processes, such as the Spanish cecina, Italian violin di capra, and the Brazilian charqui and manta (Oliveira et al., 2014; Teixeira et al., 2020). The methodologies are also not based on science. Some authors have recently studied processed goat products. Tolentino et al. (2017) studied the microbiology of newly cured products obtained from goat meat, and Teixeira et al. (2017) compared cured and mature products of the leg of goats and sheep. Another direction of research is the development of meat products with the addition of ingredients rich in polyunsaturated fatty acids in sheep meat sausages, as reported by Lima et al. (2021).

Some measures can be implemented, such as legislating standardized meat for young and certified animals, and processing 
and marketing products from older animals (Madruga \& Bressan, 2011). An acceptable presentation of meat products to the market will increase the demand for goat products and may be an alternative for the disposal of adult animal carcasses (Teixeira et al., 2020).

Smoking of goat meat products is a new option. According to Sikorski (2016), smoking is a meat preservation system, as it reduces the proliferation of microorganisms. The most important factor contributing to this is superficial dehydration, which deprives the microorganisms of the essential moisture for their growth. In addition to the phenolic compounds and formaldehyde deposited as resinous materials in meat, they have bacteriostatic properties, and phenols also provide some protection against fat oxidation. However, there are few studies on older, culled goats that report the real effects of dietary supplementation of lipids on the physical and chemical parameters of smoked meat products.

New goat meat products are still being developed, and adding flavor and value to the initial raw product by smoking, should improve acceptance in the market. The objective of this study was to investigate the effect of high-fat diets in discarded adult goats, on the physicochemical and qualitative characteristics of the shoulder meat before, during, and after dry smoking.

\section{Materials and methods}

\subsection{Animals and experimental design}

All procedures in this study were approved by the Ethics Committee in Animal Experimentation of the Ceará State University, Brazil (no 3047564/2017, CEUA-UECE).

Eighteen Anglo-Nubian cross-breed, non-lactating adult female goats ( $3.8 \pm 0.7$ years; mean $\pm \mathrm{SD}$ ) which were a surplus from the University Experimental Farm flock, were divided into two finishing diet treatments: without whole full-fat linseed $(\mathrm{WFFLG})(\mathrm{n}=9)$ and whole full-fat linseed (FFLG) $(\mathrm{n}=9)$. Goats were similar $(\mathrm{P}>0.05)$ in body weight $(33.4 \pm 3.5 \mathrm{~kg})$ and body condition scores ( $2.8 \pm 0.3$, from 1 to 5 ) upon being assigned to the groups. All animals were fed elephant grass hay and a concentrate (with ground corn grain, soybean meal, wheat bran, and a mineral mixture), provided ad libitum in a roughage to concentrate ratio of 40:60. In the FFLG group, 30\% whole full-fat linseed was added to the concentrate dry matter. Total lipid content of the diets was $2.7 \%$ and $6.9 \%$ (on a dry matter basis) for the WFFLG and FFLG groups, respectively.

In both groups, the goats received $1.5 \%$ of their body weight in concentrate feed, fed as two meals (at 08:00h and 16:00h) for 30 days until slaughter. Diets were furnished in quantity to provide 3.0 times the nutritional requirement of maintenance for adult non-dairy goats (National Research Council, 2007): a fattening program for older adult animals.

\subsection{Curing and smoking process of goat shoulder meat}

After slaughter (Brasil, 1980), carcasses were stored in a cold room at $4{ }^{\circ} \mathrm{C}$ for $24 \mathrm{~h}$ and shoulders were separated, weighed, and frozen at $-20^{\circ} \mathrm{C}$ until the curing and smoking process. The shoulders were thawed for a period of $48 \mathrm{~h}$ at $4{ }^{\circ} \mathrm{C}$ (United States Department of Agriculture, 2013). The dry curing process was performed on the fresh thawed shoulder by applying salts and condiments established in a pretest by the laboratory team, in quantities proportional to the weight of each shoulder $(15 \mathrm{~g} / \mathrm{kg} \mathrm{NaCl}, 0.3 \mathrm{~g} / \mathrm{kg}$ sodium nitrite, $2 \mathrm{~g} / \mathrm{kg}$ sugar, $0.5 \mathrm{~g} / \mathrm{kg}$ black pepper, and $0.2 \mathrm{~g} / \mathrm{kg}$ cinnamon powder), according to the limits of salts established by the regulation of inspecting products of animal origin (Brasil, 1980). In order to improve the adhesion of the mix of salts and condiments onto the raw shoulders, perforations were made in the entire muscle of the shoulder with the aid of a cutting tool. The mixture was then spread over the entire surface of the shoulder by manual friction. The shoulders were stored in a refrigerator at $4{ }^{\circ} \mathrm{C}$ for $72 \mathrm{~h}$ to complete the curing process.

The smoking process was performed in a stonework smokehouse with a height of $2.2 \mathrm{~m}$, a width of $1.5 \mathrm{~m}$, and a length of $2.0 \mathrm{~m}$, with a chimney of $17 \mathrm{~cm}$ diameter. The heat source was a brazier located in the center of the floor, with the following dimensions: $0.2 \mathrm{~m}$ depth, $0.3 \mathrm{~m}$ width, and $2.2 \mathrm{~m}$ length.

The shoulders were hung on stainless steel hooks, and the shoulders from the animals that received different treatments were distributed randomly and evenly at a height of $100 \mathrm{~cm}$ from the heat source. Charcoal (native wood) was used for combustion and heat generation. During the process, the temperature and humidity of the air were monitored using a thermohygrometer (AK624 ${ }^{\circ}$, AKSO, São Leopoldo, Brazil). The temperature in the internal environment of the smokehouse ranged from $107^{\circ} \mathrm{C}$ to $150^{\circ} \mathrm{C}$.

The smoking process lasted $6 \mathrm{~h}$, and in the final $2 \mathrm{~h}$, wood chips (Astronium lecointei) were added to the brazier for the production of smoke. The meat was considered fully cooked when the interior of the shoulder piece reached a temperature of approximately $75^{\circ} \mathrm{C}$ (United States Department of Agriculture, 2013).

\subsection{Analysis of quality parameters}

\section{Thawing loss}

The difference between fresh shoulder weight and shoulder weight after thawing was measured to determine the thawing loss of the shoulder. The thawing loss was expressed as a percentage of the initial weight, was determined using the following Equation 1:

thawing loss $[\%]=[($ weight before freezing - weight after thawing $) /$ (weight before freezing) $] \times 100$

\section{Color and $\mathrm{pH}$}

The color was determined on the forearm Tensorfasciae antebrachii shoulder muscle in the raw, and smoked state, and during the curing $(0,6,12,24,48$, and $72 \mathrm{~h})$ and smoking $(0,1,2,3,4,5$, and $6 \mathrm{~h})$. Muscle color was determined by conducting three consecutive measurements using a spectrophotometer (CM-2500 $\mathrm{d}^{\oplus}$, Japan) and a CIELAB evaluation system, with $\mathrm{L}^{*}$ corresponding to lightness, $\mathrm{b}^{*}$ to the yellow content, and $\mathrm{a}^{*}$ to the red content. The hue $(\mathrm{h} *)$ and chroma (C*) attributes were determined according to Equations 2 and 3 , and are expressed in degrees: 
$h^{*}=\arctan (b * / a *)$

$C^{*}=\sqrt{ }(a *) 2+(b *) 2 \times 57.29$

A digital pH meter (TESTO 205 ${ }^{\oplus}$, Germany) was used to simultaneously determine the $\mathrm{pH}$.

Cooking loss

Shoulder weight was recorded before and after the smoking process to measure the cooking loss in smoking. Cooking loss was calculated from the differences in the weight of the raw unsmoked and smoked samples, expressed as a percentage of the initial weight, was determined using the following Equation 4:

cooking loss $(\%)=[($ weight pre-smoking - weight post - smoking $) /$

(weight pre-smoking) $] \times 100$

\section{Water holding capacity}

The water-holding capacity was determined using the compression method. Two gram samples of the Tensor fasciae antebrachii from the raw and smoked shoulders were wrapped in filter paper and subjected to compression with a weight of $10 \mathrm{~kg}$ for $5 \mathrm{~min}$, according to the methodology described by Hamm (1960), and the results were expressed as percent release of water.

\section{Warner-Bratzler Shear Force (WBSF)}

Samples of the Tensor fasciae antebrachii muscle were analyzed before and after the smoking process to determine shear force. The samples were divided into fillets of length $2 \mathrm{~cm}$, width $1 \mathrm{~cm}$, and thickness $1 \mathrm{~cm}$, and were cut perpendicular to the direction of the muscular fibers in a texturometer (Stable Micro Systems ${ }^{\oplus}$, model TA-XT2i) equipped with a Warner-Bratzler style blade to determine the shear force (SF) in N.

\section{Chemical composition}

Samples of the Tensor fasciae antebrachii before and after smoking were used to determine the levels of dry matter (DM), ash, crude protein (CP), and ether extract (EE), methods of analysis were performed according to Association of Official Analytical Chemists (1990).

\subsection{Statistical analysis}

The data were initially submitted to a normality test (Kolmogorov-Smirnov test) and homoscedasticity test (Bartlett test) to verify the assumptions of the analysis of variance. In order to evaluate the effect of the diets on color, $\mathrm{pH}$, Warner-Bratzler shear force (WBSF), thawing loss, water holding capacity, cooking loss, and chemical composition, a completely randomized design was used. The 'Proc mix' command of the software SAS 9.0 (SAS, Inc., Cary, NC, USA) was used to evaluate the effect of the diets and the time of assessment during smoking and their interactions on color and $\mathrm{pH}$. Tukey's test was used to compare the means.
Principal component analysis and partial least squares discriminant analysis were performed using the mixOmics statistical package in the $\mathrm{R}$ programming environment (Core Team R, R Foundation for Statistical Computing, Vienna, Austria). Color characteristics, $\mathrm{pH}$, and nutrient composition were evaluated. Principal component analysis (PCA) allowed for the assessment of general variation and the identification of variables with greater discriminatory power. A p value of $5 \%$ was considered significant for differences between means.

\section{Results}

\subsection{Quality attributes}

The effect of finishing diets for adult goats containing whole linseed as a fat source on the physicochemical attributes and the chemical composition of the meat from raw and smoked shoulders are shown in Table 1. Supplementation with a high level of FFLG fat did not influence the color parameters and raw meat, but $\mathrm{pH}$ values differed $(\mathrm{p}<0.05)$ between the treated groups. However, after smoking, there was a significant effect of diet on $\left(h^{*}\right)$ in smoked shoulder meat, with lower values in the linseed treatment.

Table 1. Effect of WFFLG and FFLG supplementation lipid level on the physical attributes and chemical composition of before and after smoking process of goat shoulder meat.

\begin{tabular}{|c|c|c|c|c|}
\hline Parameters & WFFLG & FFLG & SEM $^{\#}$ & p-value \\
\hline \multicolumn{5}{|l|}{ Raw shoulder meat } \\
\hline Lightness $\left(\mathrm{L}^{*}\right)$ & 39.2 & 40.4 & 0.6 & 0.35 \\
\hline Redness $\left(\mathrm{a}^{*}\right)$ & 14.1 & 14.7 & 0.4 & 0.48 \\
\hline Yellowness $\left(\mathrm{b}^{\star}\right)$ & 11.8 & 13.1 & 0.4 & 0.06 \\
\hline Chroma $\left(\mathrm{C}^{\star}\right)$ & 18.4 & 19.6 & 0.4 & 0.19 \\
\hline Hue $\left(h^{\star}\right)$ & 40.1 & 41.7 & 0.7 & 0.31 \\
\hline $\mathrm{pH}$ & 5.3 & 5.2 & 0.01 & 0.05 \\
\hline $\mathrm{WBSF}^{*}, \mathrm{~N}$ & 35.6 & 32.4 & 1.6 & 0.32 \\
\hline Water holding capacity, \% & 31.0 & 32.0 & 0.9 & 0.57 \\
\hline Thawing loss, $\%$ & 2.9 & 2.0 & 0.3 & 0.18 \\
\hline Moisture, \% & 73.5 & 73.4 & 0.3 & 0.85 \\
\hline Ash, \% & 1.1 & 1.0 & 0.01 & 0.27 \\
\hline Fat, \% & 3.3 & 3.4 & 0.2 & 0.93 \\
\hline Protein, \% & 22.2 & 22.0 & 0.3 & 0.76 \\
\hline \multicolumn{5}{|l|}{ Smoked shoulder meat } \\
\hline Lightness $\left(\mathrm{L}^{*}\right)$ & 42.2 & 39.8 & 0.9 & 0.16 \\
\hline Redness $\left(\mathrm{a}^{\star}\right)$ & 13.3 & 14.1 & 0.3 & 0.30 \\
\hline Yellowness $\left(b^{\star}\right)$ & 9.3 & 8.3 & 0.3 & 0.09 \\
\hline Chroma $\left(C^{\star}\right)$ & 16.3 & 16.3 & 0.3 & 0.95 \\
\hline Hue $\left(h^{\star}\right)$ & 34.8 & 30.6 & 1.0 & 0.03 \\
\hline $\mathrm{pH}$ & 5.8 & 5.8 & 0.01 & 0.83 \\
\hline WBSF$^{*}, \mathrm{~N}$ & 19.3 & 17.9 & 1.1 & 0.53 \\
\hline Water holding capacity, \% & 7.1 & 9.3 & 1.0 & 0.25 \\
\hline Cooking loss, $\%$ & 38.0 & 38.9 & 0.1 & 0.41 \\
\hline Moisture, \% & 49.7 & 46.8 & 1.5 & 0.33 \\
\hline Ash, \% & 3.7 & 3.7 & 0.1 & 0.86 \\
\hline Fat, \% & 14.5 & 17.9 & 1.8 & 0.35 \\
\hline Protein, $\%$ & 11.3 & 10.8 & 0.5 & 0.65 \\
\hline
\end{tabular}

\#Standard error of the mean; *Warner-Bratzler Shear Force. 
There was no difference between the groups in the contents of moisture, ash, fat, protein, water holding capacity, thawing loss, and WBSF in raw shoulder meat (Table 1). There was no effect of diet on moisture, ash, fat, protein content, water holding capacity, cooking loss, and WBSF after the smoking process of the meat.

Figure 1 shows the effects of diet, time, and their interactions on color $\left(\mathrm{a}^{*}, \mathrm{~b}^{*}\right.$, and $\left.\mathrm{L}^{*}\right)$ and $\mathrm{pH}$ parameters during the curing process. There was a significant variation in color $\left(\mathrm{a}^{*}, \mathrm{~b}^{*}\right.$, and $\left.\mathrm{L}^{*}\right)$ as a function of time, with a reduction after $12 \mathrm{~h}(\mathrm{p}<0.01)$ with subsequent stabilization (Figure 1). The most significant change in $\mathrm{pH}$ was recorded during the first $3 \mathrm{~h}$.

The color $b^{*}$ decreased $(\mathrm{p}<0.01)$ during smoking (Figure 2$)$. On the other hand, $\mathrm{pH}$ and $\mathrm{a}^{*}$ color increased throughout the process $(p<0.01)$. Color $L^{\star}$ showed a significant interaction between diet and time $(\mathrm{p}<0.01)$, with a more pronounced reduction in the first hours for FFLG.

\subsection{Multivariate discriminant analysis}

The PCA showed that the first two principal components (PC) contributed to $46 \%$ of the total variation in raw shoulder meat, where the first and second CPs explained 26\% and $20 \%$, respectively. In smoked shoulder meat, the first two CPs contributed to $43 \%$ of the total variation, with the first and second CPs explaining 25 and $18 \%$ of the variation, respectively. In raw shoulder meat, the PCA identified that of the 14 parameters analyzed, four variables were highly correlated with $\mathrm{L}^{*}, \mathrm{a}^{*}$, $\mathrm{h}^{\star}$, and fat content. The variables aligned with PC2 are colors
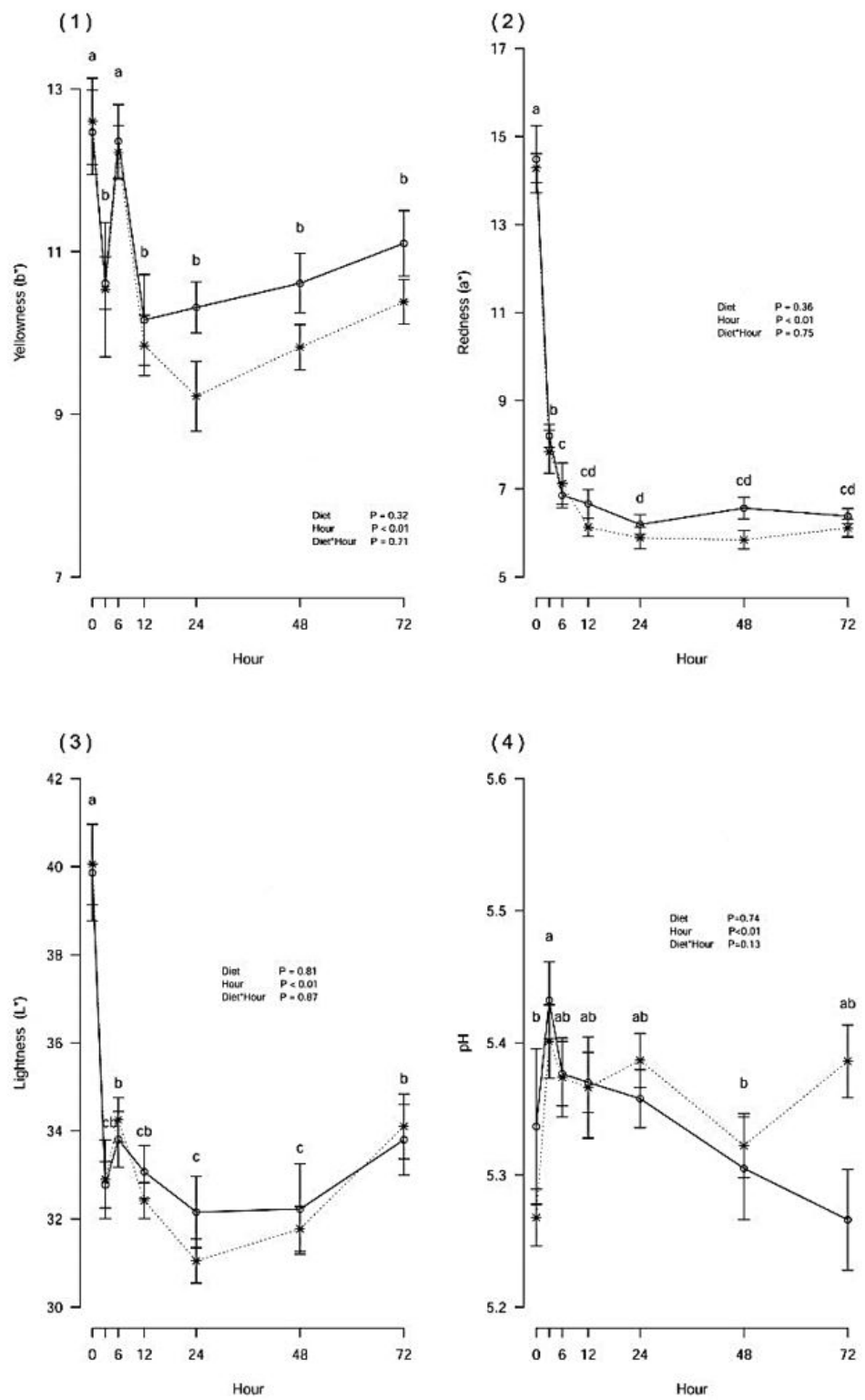

Figure 1. Effects of diet WFLLG (o) and FLLG $\left(^{*}\right)$ over time and their interactions on color Yellowness (1), Redness (2), Lightness (3) and pH (4) parameters of goat shoulder meat during the curing process. 


$$
\text { (1) }
$$

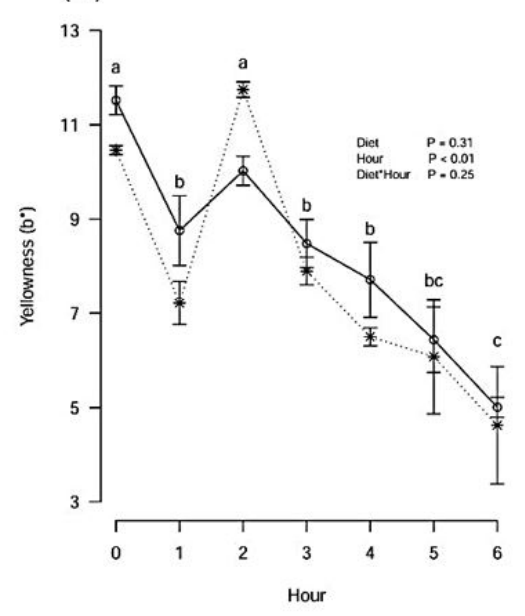

(3)

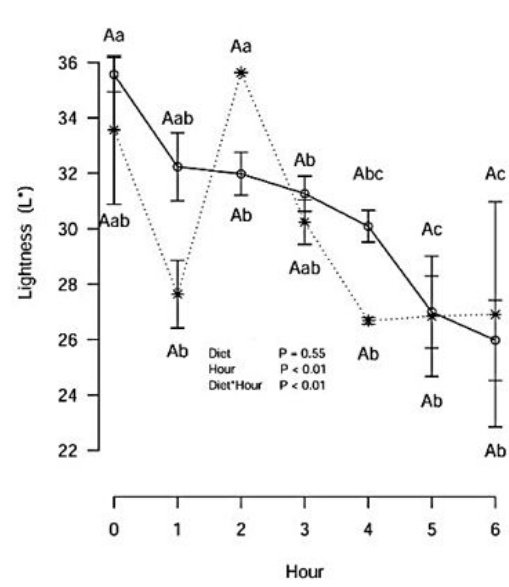

(2)

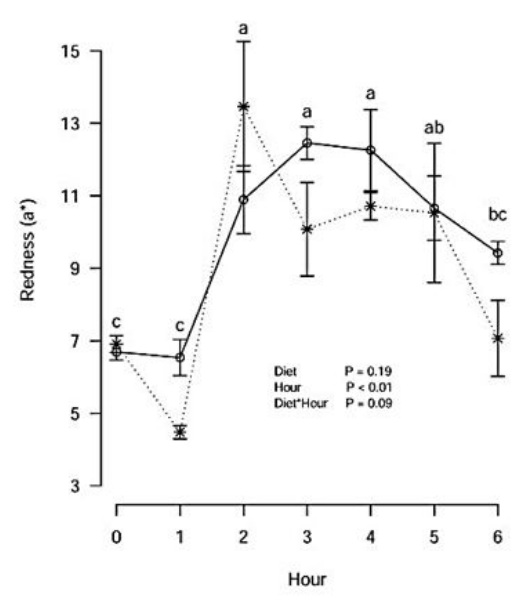

(4)

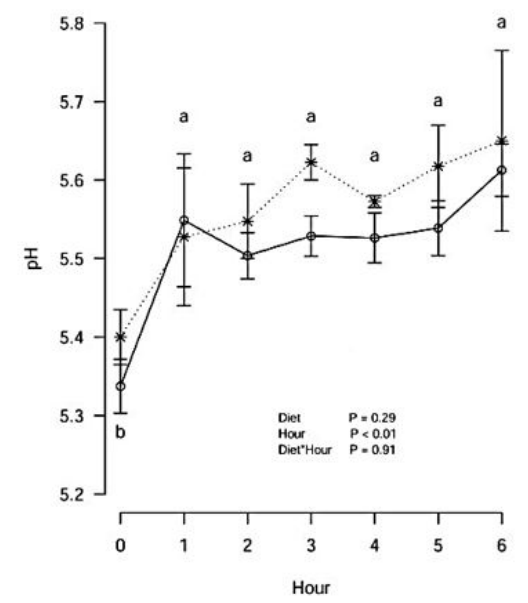

Figure 2. Effects of diet WFLLG (o) and FLLG ${ }^{*}$ ) over time and their interactions on color Yellowness (1), Redness (2), Lightness (3) and pH (4) parameters of goat shoulder meat during the smoking process.

$\mathrm{b}^{*}$ and $\mathrm{C}^{*}$. However, for smoked shoulder meat, the variables that showed a high correlation were $\mathrm{a}^{*}$ color, fat, and protein content (Table 2). Thus, it can be seen in Figure 3 that some variables highlighted in the first and second components were precisely those that were more distant from the zero point, thus corroborating the explicit data in Table 2.

\section{Discussion}

Processed goat meat products have shown interesting results in improving the physicochemical quality (Teixeira et al., 2020). Previous research have shown the importance of using goat meat to obtain processed products as a way to add value to animals with low commercial value and acceptability by consumers (Leite et al., 2015; Teixeira et al., 2020).

\subsection{Physicochemical attributes}

The colorimetric parameters of meat have great relevance in the consumer's perception of meat quality. Meats with a bright red appearance are preferable compared to meats with pale or dark colors. The color of meat is influenced by several factors, such as diet (Abuelfatah et al., 2016), species (Brand et al., 2018), type of cut, and rearing system (Ivanovic et al., 2016). The use of whole flaxseed as a fat source in the current study did not change the values of lightness $\left(\mathrm{L}^{*}\right)$, redness $\left(\mathrm{a}^{*}\right)$, and yellowness $\left(\mathrm{b}^{*}\right)$ of the raw meat. This was probably due to the fact that the fat content in the meat was similar between treatments, which is a consequence of the short-term finishing strategy. Similar results were reported by Abuelfatah et al. (2016), who evaluated different inclusion levels of flaxseed in the feed of Boer goats. According to Teixeira et al. (2011), the salting and aging process can affect the color $\left(\mathrm{h}^{\star}\right)$ of the final product, making the meat darker.

Colors varied $(\mathrm{p}<0.01)$ in the curing (Figure 1$)$ and smoking (Figure 2) processes. The color values $\mathrm{a}^{\star}, \mathrm{b}^{\star}$, and $\mathrm{L}^{\star}$ were similar to those reported by Pophiwa et al. (2017) in carcasses of Boer and native goats; however, they were higher than those reported by Teixeira et al. (2017) in cured goat legs. This divergence can be explained by the fact that they are different anatomical regions and different methods of manufacturing the products were used. The effect of myoglobin and its derivatives on the 
Table 2. Load factor for the physicochemical parametrs of each principal component (PC) of Raw shoulder meat and Smoked shoulder meat.

\begin{tabular}{|c|c|c|c|c|}
\hline \multirow{2}{*}{ Parameters } & \multicolumn{2}{|c|}{ Raw shoulder meat } & \multicolumn{2}{|c|}{ Smoked shoulder meat } \\
\hline & $\mathrm{PC1}$ & PC2 & PC1 & $\mathrm{PC} 2$ \\
\hline Weight, $g$ & -0.2561 & -0.4758 & 0.0284 & -0.0662 \\
\hline Lightness $\left(\mathrm{L}^{\star}\right)$ & 0.7474 & 0.4966 & 0.3326 & 0.4457 \\
\hline Redness $\left(\mathrm{a}^{\star}\right)$ & -0.7843 & 0.5400 & 0.8276 & 0.2235 \\
\hline Yellowness $\left(\mathrm{b}^{*}\right)$ & 0.0225 & 0.9131 & -0.0621 & 0.7852 \\
\hline Chroma $\left(\mathrm{C}^{\star}\right)$ & -0.4950 & 0.7912 & 0.6581 & 0.5812 \\
\hline Hue $\left(h^{*}\right)$ & 0.8587 & 0.3992 & -0.5669 & 0.5007 \\
\hline $\mathrm{pH}$ & -0.0689 & 0.0267 & -0.0486 & -0.4594 \\
\hline $\mathrm{WBSF}^{\star}, \mathrm{N}$ & 0.3245 & -0.1674 & -0.0010 & 0.2646 \\
\hline Water holding capacity, \% & -0.1996 & -0.2248 & 0.3579 & -0.3344 \\
\hline Thawing loss, $\%$ & 0.1369 & -0.3538 & -0.0632 & 0.4862 \\
\hline Moisture, \% & 0.5792 & -0.1350 & 0.6453 & -0.4642 \\
\hline Ash. $\%$ & 0.4553 & 0.1649 & 0.1684 & 0.1619 \\
\hline Fat, \% & -0.9070 & 0.0215 & -0.7972 & 0.3114 \\
\hline Protein, \% & -0.0933 & -0.4408 & 0.8198 & 0.3266 \\
\hline
\end{tabular}

Bold values denote the highest variability in the respective principal component.

(1)

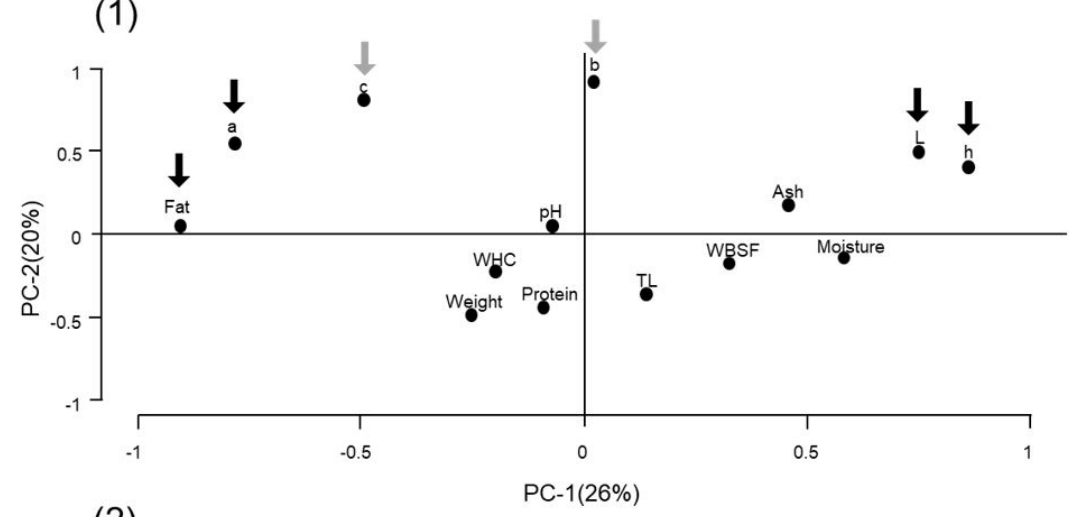

(2)

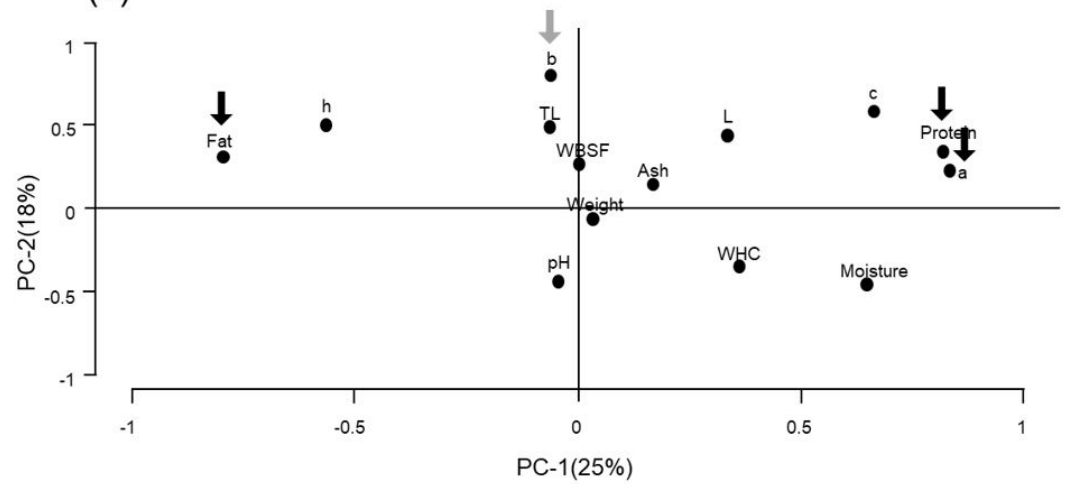

Figure 3. Two-dimensional graph of colorimetric parameters and physicochemical variables of Raw shoulder (1) and Smoked shoulder meat (2). Arrows $\downarrow$ (black) relevant parameters for PC-1, arrows $\downarrow$ (light gray) relevant parameters for PC-2. TL $=$ Thawing loss; WBSF $=$ Warner-Bratzler Shear Force; WHC = Water holding capacity.

meat surface, structure, and physical form of muscle proteins, and the proportion of intramuscular fat are the main factors responsible for the color of meat (Hughes et al., 2017).

Throughout the curing process (Figure 1), the color varied greatly in the first few hours $(\mathrm{p}<0.01)$. An inverse pattern of color $\mathrm{a}^{\star}$ stands out between the curing and smoking processes. In the curing process, the color $\mathrm{a}^{*}$ decreased rapidly in the first $12 \mathrm{~h}$ of the process, followed by stabilization. This is because nitrite or its derivatives bind to myoglobin (forming NO-myoglobin, which is responsible for the heat-stable red color in meat products) or it reacts with ascorbate, amino acids, and other compounds (Honikel, 2008). In turn, during the smoking process, the color 
indicator $\mathrm{a}^{*}$ remained stable for $1 \mathrm{~h}$ and then rose, indicating that the meat became redder. Color development on the surface of the final smoked product is also due to the presence of colors in the smoke component and its interactions with meat reactive compounds (Sikorski, 2016). The color indicators $\mathrm{b}^{*}$ and $\mathrm{L}^{*}$ decreased gradually with time $(\mathrm{p}<0.01)$. Significant interactions were observed between treatments and hours $(\mathrm{p}<0.01)$ for color $L^{\star}$, but the reasons for this are not clear.

It is well established that $\mathrm{pH}$ affects meat quality, such as color and tenderness (Simela et al., 2004). In the present study, there was no influence of diet on $\mathrm{pH}$ in fresh meat or after smoking. The samples of raw meat and after curing and smoking had $\mathrm{pH}$ values of 5.3 and 5.8, respectively. During the curing process, the $\mathrm{pH}$ increased in the first hour $(\mathrm{p}<0.01)$ and then stabilized (Figure 1). The same pattern was observed during the smoking process (Figure 2). These values are close to those reported for Boer goats (Brand et al., 2018; Pophiwa et al., 2016), and the cured (Teixeira et al., 2017) and smoked (Tolentino et al., 2017) legs of goats of mountain breeds. According to Simela et al. (2004), dark, firm, and dry goat meat (DFD) has a $\mathrm{pH}$ above 6.0. Hughes et al. (2017) stated that meat with a pH above 5.8 is considered DFD. Therefore, we can infer based on the $\mathrm{pH}$ found in the present work, that after the curing and smoking processes, the goat was DFD.

The relationship between $\mathrm{pH}$, color, and meat quality is complex and is influenced by several factors. Hughes et al. (2017) evaluated the effect of high $\mathrm{pH}$ on muscle structure and meat color, and postulated that meat of a higher $\mathrm{pH}$ has more swollen muscle fibers, thus resulting in a greater distance between the dispersion elements that limit the ability to spread light. They concluded that the structural elements that cause the lack of dispersion provide a dark meat surface and that more studies are needed to elucidate this issue.

The $\mathrm{pH}$ and parameters related to the amount of water in products are important indicators of shelf life. The current study found no difference in moisture and water holding capacity in the two groups. In the WFFLG and FFLG groups, the moisture content of raw meat $(73.5 \%$ and $73.4 \%)$ was lower after curing and smoking ( $49.7 \%$ and $46.8 \%$ ), respectively. The water holding capacity also followed this same pattern of reduction, with values of $31 \%$ and $32 \%$ before processing and $7.1 \%$ and $9.3 \%$ after smoking in the WFFLG and FFLG groups, respectively. Such reductions on moisture are in line with findings in smoked goat ham (Ivanovic et al., 2016).

One of the important physical attributes of meat quality is the tenderness, considered by the consumer as a factor in food satisfaction, which is inversely proportional to Warner-Bratzler Shear Force (WBSF). The lipid level of the diet (WFFLG and FFLG) did not influence the shear force of the meat before processing. The WBSF values were below those described by Pophiwa et al. (2016) for two goat breeds in South Africa and close to those reported by Brand et al. (2018) in the Longissimus lumborum cooked from goats fed diets of different energy levels. The shear strength of goat meat tends to be greater in the heavier carcasses of older animals than in lighter carcasses (Pratiwi et al., 2007). According to Kadim \& Mahgoub (2011), one of the explanations for toughness of adult goat meat is the higher collagen content in the connective tissue, which has a reduced ability to gelatinize under the influence of heat and humidity, and is usually associated with a low amount of intramuscular fat.

The WBSF values after curing and smoking were $19.2 \mathrm{~N}$ and $17.9 \mathrm{~N}$ for the WFFLG and FFLG groups, respectively. Such values are below those found by Ortega et al. (2016) in aged goat meat $\left(7.89 \mathrm{kgf} / \mathrm{cm}^{2} \sim 77.37 \mathrm{~N}\right)$, and the findings by Gaviraghi et al. (2007) on "violin" ham $\left(5.14 \mathrm{kgf} / \mathrm{cm}^{2} \sim 50.4 \mathrm{~N}\right)$. The use of goat meat processing methods such as salting, ageing, and drying promotes an improvement in meat tenderness, as observed by the reduction in shear force.

Thawing losses represent the loss of moisture after thawing of the carcass. Carcasses with lower fat contents could theoretically have greater moisture loss after thawing. In the present study, the fat content of various dietary treatments was similar, and diet did not have a significant effect on thawing loss ( $p>0.05)$. The thawing loss values found in the present study are close to those reported in the literature (Pophiwa et al., 2017).

Meat juiciness is affected by the amount of moisture lost during cooking, as measured by cooking loss. There was no statistical difference between the treatments $(p>0.05)$ for cooking loss (38.0 \pm 0.1$)$. On the contrary, Kadim et al. (2006) and Lee et al. (2008) reported values of between $17.5 \%$ and $25.7 \%$. The divergence of the results of these authors may have occurred due to several factors, such as final $\mathrm{pH}$, muscle type, cooking methodology (time and temperature), and age of the animals.

Nutrient supplementation may promote an increase in nutrient concentration in the meat, leading to a product of better nutritional quality (Brand et al., 2018). In the present study, there was no effect of whole linseed as a fat source on the chemical composition of raw meat or after curing and smoking. However, dietary protocols resulted in raw meats with protein levels close to $20 \%$, which is within the range recommended by Gonsalves et al. (2012) for goat meat (18\% to 22\%). Regarding fat, no significant effect of the diets was observed. Goats have more deposited fat in the viscera compared to sheep and cattle. In addition, goats have a greater ability to mobilize visceral and subcutaneous fat, allowing the species to have a lower carcass yield compared to sheep (Mendizabal et al., 2007). This peculiarity of the species associated with the short finishing period suggests, in part, that the group (WFFLG) with lower lipid content and the group (FFLG) receiving whole flaxseed as a source lipid did not present a difference in the fat content of the meat.

Scientific information about the quality parameters of smoked goat meat products is required. In a review carried out by Teixeira et al. (2020), the authors reported few studies relating smoked goat meat and measurement of physicochemical attributes of meat quality.

\subsection{Multivariate analysis}

Multivariate statistics have been used in the field of meat science to help clarify the complex relationship between meat quality and chemical composition with ante mortem factors (rearing system, diet, race, age, inter alia), making it possible to 
establish, simultaneously, the association of a several variables (Santos et al., 2008; Ribeiro et al., 2016; Lima et al., 2021).

Research on sheep meat products (Lima et al., 2021) showed that PCA based on the first two main components explained $63.47 \%$ of the global variance. As in our study, the colorimetric variables were highly relevant in explaining the general variance. Similar results were reported by Santos et al. (2008), who characterized goat meat quality.

According to Ribeiro et al. (2016), the variables that are located farther from the zero point of the longitudinal and transverse axes are the most important for the total variation. Thus, it can be observed in Figure 3 that parameters that are close to each other are positively correlated, while if they are separated by $180^{\circ}$ they are negatively correlated.

\section{Conclusion}

A high lipid finishing diet for adult female goats using whole flaxseed as a fat source, does not promote substantial alteration in the physico-chemical attributes evaluated in our study (color, $\mathrm{pH}$, shear force, water holding capacity, thawing loss, chemical composition) of cured and smoked meat. The parameters of $\mathrm{pH}$ and $\mathrm{b}^{*}$ color stand out as the most important variables to discriminate between food groups after curing and smoking following multivariate analysis. Curing and smoking methods in the meat of old goats promoted a decrease in the values of shear force in the final smoked product when compared to the meat of the shoulder raw. More studies are needed to assess whether the use of such processes can promote the use of meat less appreciated by the consumer market, making it a value-added product. As future perspectives for research on smoked goat meat products, we suggest evaluations of parameters such as fatty acid profile, lipid oxidation, volatile compounds, and sensory analysis.

\section{Acknowledgements}

The authors thank the technical team of Dr. Esaú Accioly de Vasconcelos Farm for their support and help in handling the animals. The authors would like to thanks MCTI/CNPq/MEC/ CAPES through the project Procad/Casadinho (Edital 06/2011), which support the partnership between post-graduation programs from UECE and UFRA.

\section{References}

Abuelfatah, K., Zuki, A. B. Z., Goh, Y. M., \& Sazili, A. Q. (2016). Effects of enriching goat meat with $n-3$ polyunsaturated fatty acids on meat quality and stability. Small Ruminant Research, 136, 36-42. http:// dx.doi.org/10.1016/j.smallrumres.2016.01.001.

Association of Official Analytical Chemists - AOAC. (1990). Official methods of analysis (16th ed.). Washington: AOAC.

Brand, T. S., Van Der Merwe, D. A., Hoffman, L. C., \& Geldenhuys, G. (2018). The effect of dietary energy content on quality characteristics of Boer goat meat. Meat Science, 139, 74-81. http://dx.doi.org/10.1016/j. meatsci.2018.01.018. PMid:29413680.

Brasil. (1980). Regulamento de Inspeção Industrial e Sanitária dos Produtos de Origem Animal (RIISPOA) (166 p.). Brasília.
Fiorentini, G., Messana, J. D., Dian, P. H. M., Reis, R. A., Canesin, R. C., Pires, A. V., \& Berchielli, T. T. (2013). Digestibility, fermentation and rumen microbiota of crossbred heifers fed diets with different soybean oil availabilities in the rumen. Animal Feed Science and Technology, 181(1-4), 26-34. http://dx.doi.org/10.1016/j.anifeedsci.2013.01.011.

Gaviraghi, A., Saltalamacchia, F., D’Angelo, A., Noè, L., Iacurto, M., Mormile, M., \& Greppi, G. F. (2007). Evaluation of the Violinoproducing aptitude in does e chevon: slaughter performance and meat quality. Italian Journal of Animal Science, 6(Suppl. 1), 619-621. http://dx.doi.org/10.4081/ijas.2007.1s.619.

Gonsalves, H. R. O., Sousa Monte, A. L., Villarroel, A. B. S., Damaceno, M. N., \& Cavalcante, A. B. D. (2012). Quality of goats and lambs meat: a review. Agropecuária Científica no Semiárido, 8(3), 11-17.

Hamm, R. (1960). Biochemistry of meat hydratation. Advances in Food Research, 10, 355-443. PMid:13711042.

Honikel, K. O. (2008). The use and control of nitrate and nitrite for the processing of meat products. Meat Science, 78(1-2), 68-76. http:// dx.doi.org/10.1016/j.meatsci.2007.05.030. PMid:22062097.

Hughes, J., Clarke, F., Purslow, P., \& Warner, R. (2017). High pH in beef longissimus thoracis reduces muscle fibre transverse shrinkage and light scattering which contributes to the dark colour. Food Research International, 101, 228-238. http://dx.doi.org/10.1016/j. foodres.2017.09.003. PMid:28941688.

Ivanovic, S., Nesic, K., Pisinov, B., \& Pavlovic, I. (2016). The impact of diet on the quality of fresh meat and smoked ham in goat. Small Ruminant Research, 138, 53-59. http://dx.doi.org/10.1016/j. smallrumres.2016.04.005.

Kadim, I. T., \& Mahgoub, O. (2011) Nutritive value and quality characteristics of goat meat. In O. Mahgoub, I. T. Kadim \& E. C. Webb (Eds.), Goat meat production and quality (Chap. 13). UK: CAB International, GPI Group.

Kadim, I. T., Mahgoub, O., Al-Kindi, A., Al-Marzooqi, W., \& Al-Saqri, N. M. (2006). Effects of transportation at high ambient temperatures on physiological responses, carcass and meat quality characteristics of three breeds of Omani goats. Meat Science, 73(4), 626-634. http:// dx.doi.org/10.1016/j.meatsci.2006.03.003. PMid:22062562.

Lee, J. H., Kannan, G., Eega, K. R., Kouakou, B., \& Getz, W. R. (2008). Nutritional and quality characteristics of meat from goats and lambs finished under identical dietary regime. Small Ruminant Research, 74(1-3), 255-259. http://dx.doi.org/10.1016/j.smallrumres.2007.05.004.

Leite, A., Rodrigues, S., Pereira, E., Paulos, K., Oliveira, A. F., Lorenzo, J. M., \& Teixeira, A. (2015). Physicochemical properties, fatty acid profile and sensory characteristics of sheep and goat meat sausages manufactured with different pork fat levels. Meat Science, 105, 114120. http://dx.doi.org/10.1016/j.meatsci.2015.03.015. PMid:25839884.

Lima, T. L. S., Costa, G. F., Silva Araújo, Í. B., Cruz, G. R. B., Ribeiro, N. L., Beltrão, E. M. Fo., Domínguez, R., \& Lorenzo, J. M. (2021). Pre-emulsioned linseed oil as animal fat replacement in sheep meat sausages: Microstructure and physicochemical properties. Journal of Food Processing and Preservation, 45(1), e15051. http://dx.doi. org/10.1111/jfpp.15051.

Madruga, M. S., \& Bressan, M. C. (2011). Goat meats: description, rational use, certification, processing and technological developments. Small Ruminant Research, 98(1-3), 39-45. http://dx.doi.org/10.1016/j. smallrumres.2011.03.015.

Mendizabal, J. A., Delfa, R., Arana, A., Eguinoa, P., \& Purroy, A. (2007). Lipogenic activity in goats (Blanca Celtibérica) with different body condition scores. Small Ruminant Research, 67(2-3), 285-290. http:// dx.doi.org/10.1016/j.smallrumres.2005.11.006. 
National Research Council - NRC. (2007). Nutrient requirements of small ruminants. sheep, goats, cervids, and new world camelids (pp. 39-80). Washington: National Academy Press.

Oliveira, A. F., Rodrigues, S., Leite, A., Paulos, K., Pereira, E., \& Teixeira, A. (2014). Quality of ewe and goat meat cured product mantas: an approach to provide value added to culled animals. Canadian Journal of Animal Science, 94(3), 459-462. http://dx.doi.org/10.4141/cjas2013-200.

Ortega, A., Chito, D., \& Teixeira, A. (2016). Comparative evaluation of physical parameters of salted goat and sheep meat blankets "mantas" from Northeastern Portugal. Journal of Food Measurement and Characterization, 10(3), 670-675. http://dx.doi.org/10.1007/ s11694-016-9350-z.

Pophiwa, P., Webb, E. C., \& Frylinck, L. (2016). Meat quality characteristics of two South African goat breeds after applying electrical stimulation or delayed chilling of carcasses. Small Ruminant Research, 145, 107114. http://dx.doi.org/10.1016/j.smallrumres.2016.10.026.

Pophiwa, P., Webb, E. C., \& Frylinck, L. (2017). Carcass and meat quality of Boer and indigenous goats of South Africa under delayed chilling conditions. South African Journal of Animal Science, 47(6), 794-803. http://dx.doi.org/10.4314/sajas.v47i6.7.

Pratiwi, N. M., Murray, P. J., \& Taylor, D. G. (2007). Feral goats in Australia: a study on the quality and nutritive value of their meat. Meat Science, 75(1), 168-177. http://dx.doi.org/10.1016/j. meatsci.2006.06.026. PMid:22063425.

Ribeiro, M. N., Costa, R. G., Ribeiro, N. L., Almeida, M. D., Cruz, G. R. B., \& Beltrão, E. S. Fo. (2016). Principal components analysis of the lipid profile of fat deposits in Santa Inês sheep. Small Ruminant Research, 144, 100-103. http://dx.doi.org/10.1016/j.smallrumres.2016.05.020.

Santos, V. A. C., Silva, J. A., Silvestre, A. M. D., Silva, S. R., \& Azevedo, J. M. T. D. (2008). The use of multivariate analysis to characterize carcass and meat quality of goat kids protected by the PGI "Cabrito de Barroso". Livestock Science, 116(1-3), 70-81. http://dx.doi. org/10.1016/j.livsci.2007.08.016.
Sikorski, Z. E. (2016) Smoked foods: principles and production. In B. Caballero, P. M. Finglas \& F. Toldrá (Eds.), Encyclopedia of food and health. Oxford: Academic Press. http://dx.doi.org/10.1016/ B978-0-12-384947-2.00630-9.

Simela, L., Webb, E. C., \& Frylinck, L. (2004). Post-mortem metabolic status, $\mathrm{pH}$ and temperature of chevon from indigenous South African goats slaughtered under commercial conditions. South African Journal of Animal Science, 34(Suppl. 1), 204-207.

Teixeira, A., Fernandes, A., Pereira, E., Manuel, A., \& Rodrigues, S. (2017). Effect of salting and ripening on the physicochemical and sensory quality of goat and sheep cured legs. Meat Science, 134, 163-169. http://dx.doi.org/10.1016/j.meatsci.2017.08.002. PMid:28803213.

Teixeira, A., Pereira, E., \& Rodrigues, E. S. (2011). Goat meat quality: effects of salting, air-drying and ageing processes. Small Ruminant Research, 98(1-3), 55-58. http://dx.doi.org/10.1016/j.smallrumres.2011.03.018.

Teixeira, A., Silva, S., \& Rodrigues, S. (2019). Advances in sheep and goat meat products research. Advances in Food and Nutrition Research, 87, 305-370. http://dx.doi.org/10.1016/bs.afnr.2018.09.002. PMid:30678817.

Teixeira, A., Silva, S., Guedes, C., \& Rodrigues, S. (2020). Sheep and goat meat processed products quality: a review. Foods, 9(7), 960. http://dx.doi.org/10.3390/foods9070960. PMid:32698535.

Tolentino, G. S., Estevinho, L. M., Pascoal, A., Rodrigues, S. S., \& Teixeira, A. J. (2017). Microbiological quality and sensory evaluation of new cured products obtained from sheep and goat meat. Animal Production Science, 57(2), 391-400. http://dx.doi. org/10.1071/AN14995.

United States Department of Agriculture - USDA. (2013). Smoking meat and poultry. Retrieved from https://www.fsis.usda.gov/wps/ portal/fsis/topic/food-safety-education

Webb, E. C., \& O’Neill, H. A. (2008). The animal fat paradox and meat quality. Meat Science, 80(1), 28-36. http://dx.doi.org/10.1016/j. meatsci.2008.05.029. PMid:22063167. 